\title{
ECLETIC METHOD FOR ARABIC LEARNING IN ISLAMIC SCHOOL OF INDONESIA
}

\author{
Ismail Suardi Wekke*, Muhammad Yusuf**, Agung Muttaqien*** \\ *Sekolah Tinggi Agama Islam Negeri (STAIN) Sorong \\ **Universitas Islam Negeri Alauddin, Makassar \\ ***Universitas Islam Negeri Maulana Malik Ibrahim Malang \\ iswekke@gmail.com
}

\author{
Presented in \\ International Seminar on Islamic and Arabic Education in Southeast Asia \\ Universitas Muhamamdiyah Malang \\ Malang, February 3-4, 2017
}

\begin{abstract}
Arabic learning was starting from an assumption that its method was more important than its materials. This assumption then saw that its success would be determined by methods selected by the teacher. This paper discusses the paradigm encouraged Arabic teachers to master several methods considered effective and efficient to achieve the goals of learning Arabic. Starting from this, eclectic method was born as central axis to provide various alternative methods combined to support each other in achieving the goals of learning Arabic. There were, in the past, facts showing that the causes of failures of learning foreign languages were, among others, teachers' capability to select proper and attracting methods. This statement showed that the cause was the inappropriateness of method selection which led to students' desperation. Finally, some recomendations will be presented to enhance Arabic language learning.
\end{abstract}

Keywords: eclectic, Arabic learning, teaching paradigm

\section{INTRODUCTION}

A research conducted Al-Rajhi, Bartlett, \& Altman (2013) stated that the problem in learning Arabic was the lack of passion, even in the department of Arabic language and literature. Arabic learn was also facing a fact, particularly for non-Arabs, that the very weak vocabulary mastery made students in their learning process not able to achieve simultaneous and balanced lingual skill and competency. Occasionally, listening, speaking, reading and writing skills can't be maximized simultaneously and in balance. A learning process should be departing from basic assumption that materials and their branches were a coherent whole (Gallagher, 2011; Wilson et al., 2013; Wekke, 2016).

In Arabic lesson, an aspect which often be highlighted is the learning method. It emerged due to the assumption and statement which said that "the method is more important than the materials". But, it had an antithesis which said that "teachers themselves have to learn the lessons with such difficulty before entering the classroom, let alone the students." (Mohamed, El Khouly, \& Saad, 2012; Rojas-Méndez, Papadopoulos, \& Alwan, 2015; Vassie, 2000; Wekke \& Andriansyah, 2016). The different emphasizes in Arabic lesson on the 
importance of method and the importance of materials may occur built by the reality. Tasks of an Arabic teacher were not only to teach, but also to be a motivator. So, a combination of methods is intended to cover each other's shortcomings. Operationally, method selection needs analysis and teacher ability to determine any method considered appropriate.

\section{PARADIGM OF ARABIC LEARNING PROCESS}

Paradigm of Arabic learning process is based on an opinion regarding the Arabic itself. Some parties see that Arabic with its branches is taught separately. It is marked by the separation of Arabic materials from various branches of Arabic including aspects of Arabic skill. Furthermore, this paradigm is called nazhariyyah al-furu'. There are who see that Arab is an inseparable unity which then is called nazhariyah al-wihdah. Nazhariyah al-wihdah is an approach in Arabic teaching. Nazhariyah al-wihdah consists of two words are nazhariyah and al-wihdah. Nazhariyah (نظرية) means opinion, view, theory, thought and etc., while alWihdah means unity and sometimes use the word al-wahdah (fathah on the letter waw). This writing consistently uses the term of al-wihdah (kasrah on the letter waw) (Aladdin, 2012; Halim Tamuri, Yusof Othman, Dakir, Munawar Ismail, \& Stapa, 2013; Wekke, \& Lubis, 2015). The consistence of using terms is intended to avoid any misinterpretation or misunderstanding.

Nazhariyah al-wihdah as an approach in Arabic teaching is also termed as all- in-one system. All means every, whole and each . All-in-one (in the form of idiom) means all is existing, while system a noun meaning structure and way (Kleinsasser, 2013). It is commented that system meant thariqah, nizham and tartib (Makhdoom, Khoshhal, Algaidi, Heissam, \& Zolaly, 2013). All-in-one system is literally translated as multi or whole. All-inone system (nazhariyah al-wihdah), terminologically, is a system or approach in Arabic teaching viewing that Arabic is a unity that cannot be separated (Aladdin, 2013a; Ghani, Ahmad, Hashim, Shaadon, \& Mustapa, 2012; Jamous \& Chik, 2012; Wekke \& Hamid, 2013).

All-in-one system is defined in which a language is taught as parts arranged as unity, not separated or different branches (Alabdulkader \& Leat, 2015). Based on this, it can be modeled that nazhariyah al-wihdah is a theory seeing that Arabic and its branches are actually one unified whole. Achieving one part (branch) should not cause an Arabic student to ignore other parts since all parts are an inseparable unity. Arabic learn can run maximally when the teacher is mastering both method and substance at once. As for the theory saying that method is more important than materials, there is a context underlying that. The fact 
shows that there are such difficulties frequently found in Arabic learn since the teachers themselves are not mastering the materials. In this context, it can be said that the mastery of the materials is important before implementing other learning methods. Essentially, both method and material are two things are mutually supporting, so that, they cannot be separated within Arabic learn (Dajani \& Omari, 2014; Hamed, 2012).

\section{Nazhariyah al-Wihdah: an Approach in Arabic Learn}

The idea about nazhariyah al-wihdah is an idea to achieve Arabic skill which is shown when the Arabic teaching is done separately from each of its branches (Volkovich, Granichin, Redkin, \& Bernikova, 2016; Zuhurudeen \& Huang, 2016). To avoid to be protracted in these weaknesses, tangible steps and anticipatory steps which can be done are the all-in-one system as an approach in Arabic teaching. This approach views that Arabic teaching should refer to the principles of all-in-one system meaning that Arabic learning materials should be considered as an inseparable unity of each branch (Lou \& Noels, 2016; Menai, 2014; Schwartz \& Asli, 2014), not furu'iyah. Paradigm of Islamic boarding school sees that Arabic learn still should be separated from its branches though such overall branches are leading to the mastery of Arabic language as a whole. Whereas the Arabic learn, on the version of Islamic school, is done integrally between all its branches including handbooks used and all skills as a whole and taught integrally including listening, speaking, reading and writing skills. Both Islamic boarding school and Islamic school, actually, agree on that Arabic language is a unity, but techniques of learn may be different. The important one is that they should be done in balance and consistently (Kern, Lingnau, \& Paul, 2015; Khayyat, Lam, \& Suen, 2014).

As an approach of Arabic learning process, nazhariyah al-wihdah seems to be consistent upon its principles. In order to achieve its goals, nazhariyah al-wihdah is consistent upon its principles including: First, Principle of Psychology. Arabic learn in the approach of nazhariyah al-wihdah (all-in-one system) always has meaningful refreshment about students' activities and passion. Using this approach, there is motivation to improve the passion to learn because there is diversity in the approach and not monotonous (Al-Amer, Ramjan, Glew, Darwish, \& Salamonson, 2016; Alfahad, 2015). A good teacher is a teacher being creative and smart to motivate his/her students to that the difficulties faced by the students, which caused by their internal factors stultifying their passion, can be solved (Ahmad, Mahmoud, \& Fink, 2016; Bonacina-Pugh, 2013; Raymond, Jacob, Jacob, \& Lyons, 2016). In line with this, it is a comment that motivation in Arabic learn should be developed 
continuously by embedding a feeling of "yes, I can" (Alruily, Ayesh, \& Zedan, 2014; Bounhas, Ayed, Elayeb, \& Bellamine Ben Saoud, 2015; Chakrani, 2015; Garca-Sanchez, 2010; Germanos \& Miller, 2015; Suleiman, 2011). Furthermore, he commented that the way to achieve that is by avoid any emphasis on giving terms (fa'il, maf'ul, majrur, mansub, marfu' etc.), moreover for non-Arabic department and beginners.

This all-in-one education system can provide motivation and grow students' interest to learn, particularly, Arabic language. This approach also requires the students to understand situation depicted by learning materials deductively. Reviews delivered by the teachers after giving each material should be solved on each aspect to strengthen their understanding about such material (Alomar, Wanick, \& Wills, 2016; Chaibi, Naili, \& Sammoud, 2014; Dajani, 2015). At the beginning, on the sidelines, or at the end of each meeting, Arabic teacher, which is simultaneously being motivator for his/her students to understand that Arabic language is important for them now and in the future and learning Arabic language is not difficult when they are paying great attention to it and doing practices seriously and intensively.

Second, Pedagogical Principles. A language teacher who teaches Arabic language should know that learning materials are related to each other. Teaching Arabic language, a teacher should consider to how to achieve four aspects are istima', kalam/muhadatsah, kitabah and qira'ah in balance without any separation in mastering by stressing on one of those four skills (Cronj, 2011). The four lingual competencies/skills should be taught and trained to the students so that they may grow in balance and integrally (Alabdulkareem, 2015; Omari, 2015).

This all-in-one system approach is very suitable and worthy to be studied using Gestalt theory in balance, at the same time (Oktay, 2015). This theory has a principle that learning is based on the overall, development, transferring occurrence, and will be more successful when suitable with the interest, and continuously (Aladdin, 2014). These principles of this theory seem to be more effectively leading to the success of learning Arabic. In this method of Arabic learn, besides support of method, motivation and students interest, there is environmental factor which is also significantly determining the success or the failure of an Arabic learning process.

Arabic learn always considers to principles, methods materials and environment. Embedding motivation to the students to learn Arabic language is also an aspect participating to determine the strength of further learning interest consistently. To realize this objective, Arabic language teachers should previously ensure the students that Arabic language would 
give them many advantages in the future. The teachers should attempt to ensure them that Arabic language is not difficult (Sirajudeen \& Adebisi, 2012; Zedan et al., 2013; Wekke, 2013). Therefore, Arabic language teachers are not only required to teach Arabic language, but also - like what has been mentioned above - being motivators for their students. When this can be done well by the Arabic language teachers, the teaching process will exactly prove that Arabic language is not as difficult as what they were worried about but it is easy. The solution is how to make Arabic language to be interesting and easy to understand. Besides those, the most determining aspect is favorable learning environment. Generally, Islamic boarding schools have a high commitment to take Arabic language as daily language in their environment, so that times for learning Arabic are more often outside of formal sessions like in activities relating to the boarding school status or even, there are lingual courts. Meanwhile, Islamic schools experience an obstacle that is limited time allocation as they just have formal session that is just for 2 hours per week.

Third, Principles of Linguistics. The principles of all-in-one system approach are in line with listening, speaking, writing and reading activities. When there is one who wants to express an idea stimulated by hearing sense, there will be an attempt to discuss it both using spoken and written language (Aladdin, 2013b). Principles of linguistics state that language is ideas expressed orally, not imprisoned in the deepest heart without any execution/expression and without involving language functions (Dajani, Mubaideen, \& Omari, 2014). This principle requires languages to function and to be realized in the form of communication.

\section{CONCLUSION}

Whenever this principle is becoming standard of language learning process, it means that language, actually, is a means of communication which is actively used to deliver ideas. Therefore, to put language functioning as it should be, its learning process should be communicative, given that the principle that language is a means of communication. Islamic boarding school more obviously establish the principles of linguistics since their students are fully living in the boarding schools which is different with Islamic school where the students are living at the schools just at the formal times or school days.

\section{REFERENCE}

Ahmad, I., Mahmoud, S. A., \& Fink, G. A. (2016). Open-vocabulary recognition of machineprinted Arabic text using hidden Markov models. Pattern Recognition (Vol. 51). Elsevier.

Alabdulkader, B., \& Leat, S. J. (2015). Toward developing a standardized Arabic continuous 
text reading chart. Journal of Optometry, 1-11.

Alabdulkareem, S. A. (2015). Exploring the Use and the Impacts of Social Media on Teaching and Learning Science in Saudi. Procedia - Social and Behavioral Sciences, $182,213-224$.

Aladdin, A. (2012). Analisis penggunaan strategi komunikasi dalam komunikasi lisan Bahasa Arab. GEMA Online Journal of Language Studies, 12(2), 645-666.

Aladdin, A. (2013a). An investigation into the attitudes of the Non-Muslim Malaysian Learners of Arabic (NMMLA) toward learning of Arabic as a foreign language. Pertanika Journal of Social Science and Humanities, 21(SUPPL), 183-196.

Aladdin, A. (2013b). Demotivating Factors in the Arabic Language Clasroom: What Demotivates non-Muslim Malaysian Learners when it Comes to Learning Arabic? Procedia - Social and Behavioral Sciences, 93(60389254577), 1652-1657.

Aladdin, A. (2014). The Importance of Immediate Learning Context: An Investigation on the Arabic as a Foreign Language Classroom. Procedia - Social and Behavioral Sciences, $118,56-60$.

Al-Amer, R., Ramjan, L., Glew, P., Darwish, M., \& Salamonson, Y. (2016). Language translation challenges with Arabic speakers participating in qualitative research studies. International Journal of Nursing Studies, 54, 150-157.

Alfahad, A. (2015). Aggressiveness and deference in Arabic broadcast interviews. Journal of Pragmatics, 88, 58-72.

Alomar, N., Wanick, V., \& Wills, G. (2016). The design of a hybrid cultural model for Arabic gamified systems. Computers in Human Behavior, 64, 472-485.

Al-Rajhi, I., Bartlett, D., \& Altman, Y. (2013). Research note: the development of an Arabic cross-cultural adjustment scale. Cross Cultural Management: An International Journal, 20(3), 449-463.

Alruily, M., Ayesh, A., \& Zedan, H. (2014). Crime profiling for the Arabic language using computational linguistic techniques. Information Processing and Management, 50(2), 315-341.

Bonacina-Pugh, F. (2013). Multilingual label quests: A practice for the "asymmetrical" multilingual classroom. Linguistics and Education, 24(2), 142-164.

Bounhas, I., Ayed, R., Elayeb, B., \& Bellamine Ben Saoud, N. (2015). A hybrid possibilistic approach for Arabic full morphological disambiguation. Data and Knowledge Engineering, 100, 240-254.

Chaibi, A. H., Naili, M., \& Sammoud, S. (2014). Topic segmentation for textual document written in Arabic language. Procedia Computer Science, 35(C), 437-446.

Chakrani, B. (2015). Arabic interdialectal encounters: Investigating the influence of attitudes on language accommodation. Language and Communication, 41, 17-27.

Cronj, J. C. (2011). Using Hofstede's cultural dimensions to interpret cross-cultural blended teaching and learning. Computers and Education, 56(3), 596-603.

Dajani, B. A. S. (2015). Teaching Arabic Language: Towards a New Beginning that Stimulates Creativity. Procedia - Social and Behavioral Sciences, 192, 758-763.

Dajani, B. A. S., \& Omari, F. M. A. (2014). A Critical Study of Three Textbooks for Teaching Arabic to Non-native Speakers. Procedia - Social and Behavioral Sciences, $114,476-481$.

Dajani, B. A. S., Mubaideen, S., \& Omari, F. M. A. (2014). Difficulties of Learning Arabic for Non-native Speakers. Procedia - Social and Behavioral Sciences, 114, 919-926.

Gallagher, K. (2011). Bilingual education in the UAE: factors, variables and critical questions. Education, Business and Society: Contemporary Middle Eastern Issues, 4(1), $62-79$.

Garca-Sanchez, I. M. (2010). The politics of Arabic language education: Moroccan 
immigrant children's language socialization into ethnic and religious identities. Linguistics and Education, 21(3), 171-196.

Germanos, M. A., \& Miller, C. (2015). Is religious affiliation a key factor of language variation in Arabic-speaking countries? Language and Communication, 42, 86-98.

Ghani, S. A., Ahmad, S. Z. @ H., Hashim, U. H. H., Shaadon, Z., \& Mustapa, N. S. (2012). Application of basic Skills in Reading Arabic Text for Teaching and Learning Maharat Al-Qiraah. Procedia - Social and Behavioral Sciences, 59, 26-32.

Halim Tamuri, A., Yusof Othman, M., Dakir, J., Munawar Ismail, A., \& Stapa, Z. (2013). Religious education and ethical attitude of Muslim adolescents in Malaysia. Multicultural Education \& Technology Journal, 7(4), 257-274.

Hamed, A. (2012). The Utilization of Technology in Teaching of the Arabic Language in Secondary Schools in Riyadh, Saudi Arabia. Procedia - Social and Behavioral Sciences, 64(0), 594-603.

Jamous, R., \& Chik, A. R. (2012). Teaching Arabic for Cultural Purposes: A Case Study of Francophone Program of Arabic at Aleppo University. Procedia - Social and Behavioral Sciences, 66(May), 37-45.

Kern, F., Lingnau, B., \& Paul, I. (2015). The construction of "academic language" in German classrooms: Communicative practices and linguistic norms in "morning circles." Linguistics and Education, 31, 207-220.

Khayyat, M., Lam, L., \& Suen, C. Y. (2014). Learning-based word spotting system for Arabic handwritten documents. Pattern Recognition, 47(3), 1021-1030.

Kleinsasser, R. C. (2013). Language teachers: Research and studies in language(s) education, teaching, and learning in Teaching and Teacher Education, 1985-2012. Teaching and Teacher Education, 29(1), 86-96.

Lou, N. M., \& Noels, K. A. (2016). Changing language mindsets: Implications for goal orientations and responses to failure in and outside the second language classroom. Contemporary Educational Psychology, 46, 22-33.

Makhdoom, N., Khoshhal, K. I., Algaidi, S., Heissam, K., \& Zolaly, M. A. (2013). "Blended learning" as an effective teaching and learning strategy in clinical medicine: A comparative cross-sectional university-based study. Journal of Taibah University Medical Sciences, 8(1), 12-17.

Menai, M. E. B. (2014). Word sense disambiguation using evolutionary algorithms Application to Arabic language. Computers in Human Behavior, 41, 92-103.

Mohamed, A. a., El Khouly, S., \& Saad, M. (2012). Reliability and factor structure of a trait emotional intelligence measure in four Arab countries. Education, Business and Society: Contemporary Middle Eastern Issues, 5(1), 83-92.

Oktay, A. (2015). Foreign Language Teaching: A Problem in Turkish Education. Procedia Social and Behavioral Sciences, 174, 584-593.

Omari, F. M. A. (2015). Teaching Syntax for Non-Arabic Speakers. Procedia - Social and Behavioral Sciences, 185, 388-391.

Raymond, A., Jacob, E., Jacob, D., \& Lyons, J. (2016). Peer learning a pedagogical approach to enhance online learning: A qualitative exploration. Nurse Education Today, 44, 165169.

Rojas-Méndez, J. I., Papadopoulos, N., \& Alwan, M. (2015). Testing self-congruity theory in the context of nation brand personality. Journal of Product \& Brand Management, 24(1), 18-27.

Schwartz, M., \& Asli, A. (2014). Bilingual teachers' language strategies: The case of an Arabic-Hebrew kindergarten in Israel. Teaching and Teacher Education, 38, 22-32.

Sirajudeen, A., \& Adebisi, A. (2012). Teaching Arabic as a Second Language in Nigeria. Procedia - Social and Behavioral Sciences, 66, 126-135. 
Suleiman, Y. (2011). Arabic, Self and Identity: A Study in Conflict and Displacement. Arabic, Self and Identity: A Study in Conflict and Displacement, 42, 1-288.

Vassie, R. (2000). Improving access in bilingual, biscript catalogues through Arabised authority control. Online Information Review, 24(6), 420-429.

Volkovich, Z., Granichin, O., Redkin, O., \& Bernikova, O. (2016). Modeling and visualization of media in Arabic. Journal of Informetrics, 10(2), 439-453.

Wekke, I. S. (2013). Islam di Papua Barat: tradisi dan keberagaman. ULUL ALBAB Jurnal Studi Islam, 14(2).

Wekke, I. S. (2016). Pengembangan kurikulum pendidikan agama Islam muslim minoritas: pesantren Nurul Yaqin Papua Barat. MADRASAH, 6(2), 26.

Wekke, I. S., \& Andriansyah, A. (2016). From Gontor to Sorong: Muslim Minority Practices on Arabic Teaching and Learning. SOSIOHUMANIKA, 9(1).

Wekke, I. S., \& Hamid, S. (2013). Technology on language teaching and learning: a research on Indonesian pesantren. Procedia-Social and Behavioral Sciences, 83, 585-589.

Wekke, I. S., \& Lubis, M. A. (2015). Educational Technology on Teaching and Learning of Integrated Islamic Education in Brunei Darussalam. Ulumuna, 15(1), 185-204.

Wilson, J. a. J., Belk, R. W., Bamossy, G. J., Sandikci, Ö., Kartajaya, H., Sobh, R., ... Scott, L. (2013). Crescent marketing, Muslim geographies and brand Islam. Journal of Islamic Marketing (Vol. 4).

Zedan, A. M., Kadir, F. A. B. A., Yusof, M. Bin, Yusoff, Y. B. M., Siren, N. B. H., Mohamed, R. Bin, \& Toure, S. (2013). The Role of Language in Education: Arabic as Case Study. Procedia - Social and Behavioral Sciences, 70, 1002-1008.

Zuhurudeen, F. M., \& Huang, Y. T. (2016). Effects of statistical learning on the acquisition of grammatical categories through Qur'anic memorization: A natural experiment. Cognition, 148, 79-84. 